\title{
The Struggle of Fiqh Reasoning in The Implementation of MUI's Fatwa on Worship During Pandemic in The Island of Lombok
}

\author{
Muhamad War'i \\ Sekolah Tinggi Ilmu Tarbiyah Darussalimin NW Praya. akmaly.warok@gmail.com
}

\begin{abstract}
This paper discusses the implementation of MUI's fatwa on worship during Covid-19 pandemic. Social facts show that the implementation of the fatwa has given rise to various socio-religious conflicts in Lombok island. Through a qualitative approach, the paper concludes: First, the people of Lombok Muslim community disapprove the fatwa. Second, there is a conceptual difference between the government as the beholder of the MUI's fatwa and the community's religious traditions that have been maintained for a long time. Third, the model of figh law reasoning used by the government in general is a textual (normative) model that is contrary to society's use of historical meaning. Therefore, a dialogical process is needed for a solution to social problems that occur as a result of the implementation of the ulama's fatwa which is used as government policy so that it does not appear to be coercive by involving elements of ulama, goverment, and society. The dialog conectivity of these three elements in negotiating their understandings of figh to place the intent and purpose of a legal product (fatwa) will encourage the realization of inclusive figh reasoning.
\end{abstract}

Keywords: fiqh reason, MUI's fatwa, mosque closing

\section{Pergulatan Nalar Fikih dalam Implementasi Fatwa MUI tentang Ibadah saat Wabah di Pulau Lombok}

\begin{abstract}
Abstrak
Tulisan ini mengkaji secara fenomenologis implementasi fatwa MUI tentang ibadah di tengah pandemi wabah Covid-19. Fakta sosial menunjukkan bahwa implementasi fatwa tersebut telah melahirkan berbagai konflik sosial keagamaan di Pulau Lombok. Melalui pendekatan kualitatif tulisan berkesimpulan: Pertama, respon masyarakat muslim Lombok sebagai demografi dengan banyaknya masjid adalah adanya ketidakmenerimaan baik secara psikologis, sosial, dan kultural. Kedua, terjadi pertentangan konseptual antara pemerintah selaku pemegang fatwa MUI dengan konsep tradisi keagamaan masyarakat yang telah lama ada dan menjadi pedoman mereka. Ketiga, model penalaran hukum fikih yang digunakan pemerintah secara umum adalah model pemaknaan tekstual (normatif) bertentangan dengan masyarakat yang menggunakan pemaknaan historis. Oleh karena itu, dibutuhkan proses dialogis sebagai langkah solutif atas problem sosial yang terjadi akibat implementasi fatwa ulama yang dijadikan kebijakan pemerintah agar tidak terkesan memaksa dengan melibatkan unsur ulama, umara', dan mujtama'. Konektivitas dialog tiga unsur ini dalam menegosiasikan pemahaman fikih mereka untuk mendudukkan maksud dan tujuan suatu produk hukum (fatwa) akan mendorong terwujudnya nalar fikih yang inklusif.
\end{abstract}

Kata Kunci: nalar fikih, fatwa MUI, penutupan masjid

* Naskah diterima September 2021, direvisi Oktober 2021, dan disetujui untuk diterbitkan November 2021

Dialog, 44 (2), 2021, 230-244

https://jurnaldialog.kemenag.go.id,p-ISSN: 0126-396X,e-ISSN: 2715-6230

This is open access article under CC BY-NC-SA-License

(https://creativecommons.org/license/by-nc-sa/4.0/)

Dialog Vol. 44, No.2, Desember 2021

230 


\section{A. Pendahuluan}

Fatwa Majelis Ulama Indonesia (MUI) tentang ibadah di tengah wabah yang tertuang dalam fatwa Nomor 14 Tahun 2020 telah menjadi salah satu bahasan panjang masyarakat Muslim Indonesia. Poin yang paling disorot adalah peniadaan salat Jumat dan diganti salat Zuhur. Pro dan kontra pun terjadi. Sebagian mendukung fatwa tersebut, sebagian lainnya menolak. Sebagai negeri mayoritas muslim, proses perubahan kultural ritual keagamaan masyarakat yang telah mentradisi dalam praktik-praktik keberagamaan nampaknya tidak mudah diubah hanya dengan lembar surat fatwa MUI. Larangan beribadah di tempat-tempat ibadah di masa pandemi faktanya telah meninggalkan berbagai konflik yang tidak sederhana.

Di pulau Lombok misalnya, sebagai pulau yang memiliki banyak masjid sehingga dikenal sebagai Pulau Seribu Masjid juga mengalami konflik sosial keagamaan seiring implementasi fatwa MUI tentang ibadah di masa pandemi virus Corona. Tercatat sejak pertama kali fatwa tersebut dikeluarkan, telah memunculkan polemik di berbagai komunitas masyarakat. Terjadi pertengkaran yang berdarah antara TNI dan jamaah masjid di salah satu daerah di Lombok Tengah. Hal yang sama juga terjadi di daerah Lombok lainnya.

Nampaknya apa yang dialami masyarakat muslim pulau seribu masjid dan komunitas muslim lainnya secara nasional dalam menyikapi implementasi fatwa MUI telah menjadi bahasan banyak kalangan akademisi. Sebagaimana yang terdokumentasikan dalam berbagai tulisan ilmiah, kajian seputar fatwa MUI terutama tentang fatwa di tengah wabah telah dikaji dalam berbagai perspektif. Mushoddiq dan Imron mengatakan bahwa MUI selaku aktor hukum memiliki peran yang sangat dominan dalam konstruksi sosial masyarakat muslim Indonesia (Mushodiq \& Imron, 2020: 455-472).

Di samping itu, Fatwa MUI juga dinilai cendrung ketat dalam konteks untuk diterapkan dalam masyarakat (Rusyana, 2020). Ini mungkin salah satu yang menjadi faktor seringnya muncul problem sosial dalam implementasi fatwa MUI di tengah masyarakat. Salah satu contoh kasus problem ini adalah adanya penolakan Jamaah Tabligh terhadap fatwa MUI. Ini mengingat komunitas keagamaan tersebut selalu identik dengan kegiatan yang bersifat publik (jamaah) (Dahlan, 2020). Meskipun demikian, beberapa riset juga menyebutkan bahwa fatwa hukum MUI tentang libur Jumat bisa dan layak menjadi pegangan masyarakat dalam tradisi keagamaan mereka di era pandemi (Zulkarnain et al., 2020). Pun juga dalam salah satu riset disebutkan bahwa masyarakat Muslim Indonesia memiliki kemenerimaan yang positif terhadap fatwa MUI (Hanafi et al., 2020).

Berbagai kajian tersebut sebagian besar terpaku pada MUI secara institusi serta produk fatwanya, dan tidak banyak mengkaji tentang posisi objek fatwa yakni masyarakat umum. Apa yang terjadi di pulau Lombok memberikan peluang kajian untuk menghadirkan fatwa MUI dalam sudut implementasinya yakni ketika fatwa telah 'dilemparkan' ke dalam lahan sosial yang luas dan beragam. Implementasi fatwa MUI ini faktanya telah menjadi problem serius karena tidak hanya terbatas pada perdebatan verbal kelompok pro dan kontra semata, bahkan telah melahirkan konflik berdarah yang mengkhawatirkan.

Kenyataan tersebut mendorong penulis untuk menganalisis implementasi fatwa MUI terutama tentang ibadah di tengah wabah. Ada dua problem krusial yang bisa dihadirkan dalam tulisan ini. Pertama, adanya pertentangan konseptual (nalar fikih) antara masyarakat sebagai objek fatwa dengan Pemerintah sebagai subjek fatwa karena menggunakan fatwa MUI sebagai landasan kebijakan penanganan Covid-19. Artinya pemahaman fikih masyarakat yang bersifat normatif dan konvensional bahkan mentradisi seolah menemukan hentakan keras dengan kerangka konsep fikih yang dikeluarkan MUI melalui fatwanya.

Kedua, perlu disikapi dengan serius solusi dari konflik sosial keagamaan yang disebabkan oleh implementasi fatwa MUI 
tersebut, karena hingga saat ini meski sudah lebih dari satu tahun berlalu sejak fatwa dikeluarkan, bangunan keberagamaan masyarakat kita masih cukup rapuh terutama dalam memahami dan menyikapi penerapan hasil fatwa dalam ritual keagamaan yang selama ini telah mentradisi dalam diri masyarakat muslim Lombok.

Penelitian ini menghadirkan bahasan tentang konflik sosial keagamaan yang terjadi setelah implementasi fatwa MUI Nomor 14 tentang ibadah di tengah wabah dengan pergolakan konseptual yang sepertinya telah menjadi dua bangunan terpisah antara konsepsi masyarakat muslim Lombok dengan kerangka konsep yang digunakan Satgas Covid (pemerintah) saat menggunakan fatwa keagamaan dalam kebijakan teknisnya. Hal ini penting untuk meperlihatkan formasi nalar masyarakat terutama dalam konteks hukum fikih sehingga memberikan informasi mendasar tentang bangunan pemahaman keagamaan (fikih) masyarakat kita.

Pemetaan nalar ini penting untuk merekonsiliasi konflik sosial keagamaan yang masih sering muncul dan tak terhindarkan, dan mungkin juga akan banyak terjadi di masa depan. Ini mengingat istilah nalar mengandung komponen kehidupan yang kompleks berupa tradisi sosial, politik, kebudayaan, dan lainnya. Pembahasan ini diharapkan mampu mengisi ruang kosong yang ditinggalkan beberapa penelitian terdahulu terhadap fatwa MUI terutama dari sisi implementasinya.

Setidaknya ada tiga problem yang menjadi pertanyaan riset dalam tulisan ini. Bagaimana respon masyarakat muslim terhadap fatwa ibadah di tengah wabah di pulau seribu masjid (Lombok)? Bagaimana pertentangan konseptual antara fatwa MUI dengan nalar fikih masyarakat? Apa dampak sosial keagamaan yang ditimbulkan fatwa MUI? Dengan demikian tulisan ini bertujuan untuk mengelaborasi respon masyarakat muslim di pulau seribu masjid terhadap fatwa MUI tentang ibadah di masa pandemi, memetakan nalar fikih masyarakat melalui sikap dan kemenerimaan mereka terhadap fatwa tersebut, serta dampak-dampak sosiologis yang dimunculkan.

Selain ketiga bahasan tersebut, tulisan ini pada bagian akhir akan memberikan refleksi dari uraian tentang hal ini sebagai bagian dari tanggung jawab intelektual penulis yakni dengan memberikan solusi dari dampak konflik sosial yang terjadi juga sebagai inspirasi untuk pengelolaan konflik ke depannya terkait dengan implementasi fatwa Majelis Ulama Indonesia.

Penelitian ini urgen dihadirkan dengan berbagai alasan. Pertama, secara teoritis tulisan ini memberikan sumbangan penerapan model riset fenomenologi dalam ranah penerapan hukum fikih, suatu kajian yang mungkin masih jarang digunakan dalam riset-riset serupa. Kedua, secara akademik, tulisan ini akan memberikan inspirasi bagi para akademisi dalam melakukan kajian-kajian hukum atau kebijakan-kebijakan publik dengan menggunakan pendekatan multi-perspektif. Hal ini mengingat tulisan ini meskipun sekilas menggunakan metode fenomenologi sebagai kacamata, tetapi dalam kerangka teoritiknya menggunakan berbagai teori yang relevan untuk mempertajam dan melebarkan analisis.

Adapun yang ketiga, secara praktis, tulisan ini bisa menjadi referensi bagi Majelis Ulama Indonesia dan pemerintah dalam mengimplementasikan fatwa yang dikeluarkan. Artinya dengan data ini, MUI bisa melakukan pertimbanganpertimbangan sosial maupun kebudayaan dalam mengeluarkan fatwa yang terutama digunakan pemerintah dalam penerapan kebijakan. Ini mengingat ketika fatwa digunakan pemerintah untuk menerapkan suatu kebijakan, seringkali hasil fatwa tersebut berbau final dan subjektif. Sesuatu yang kemudian seringkali melahirkan konflik sebagaimana yang telah penulis singgung sebelumnya.

\section{B. Metode Penelitian}

Tulisan ini adalah penelitian berparadigma fenomenologi dengan pendekatan riset kualitatif. Penelitian ini 
memadukan model penelitian lapangan (field research) dan penelitian kepustakaan (library research). Penggabungan dua model penelitian ini untuk memberikan deskripsi yang lebih mendalam. Melalui riset lapangan penulis mengumpulkan pandangan subjek riset yakni informan dan key informan. Sedangkan melalui penelitian kepustakaan penulis membedah tentang konsep-konsep teoritik yang relevan dengan bahasan dalam penelitian ini.

Penelitian ini bukanlah kajian hukum (fikih) tetapi merupakan kajian fenomena keagamaan. Oleh karena itu, penulis menyebut kajian ini sebagai studi agama. Secara teoritik, studi agama mengalami bentang sejarah yang panjang. Penggunaan perangkat sosiologi dalam mengkaji tradisi keagamaan bukanlah hal baru. Para sosiolog telah menghabiskan berpuluh-puluh tahun dalam merumuskan konsep yang relevan.

Dalam kajian kontemporer, studi agama juga mengalami perubahan yang cukup pesat. Di Indonesia kajian studi agama dimotori oleh para akademisi dari kampuskampus Islam (UIN / IAIN). Amin Abdullah menjadi salah satu teoritikus yang cukup populer. Melalui konsep integrasiinterkoneksi, namanya selalu disinggung dalam kajian studi agama.

Adapun kajian fenomenologi dalam studi agama juga telah banyak digunakan. Istilah Fenomenologi sejatinya akrab dengan beberapa istilah serupa seperti Sosiologi Pengetahuan, Etnografi, dan Hermeneutika Sosial. Penulis menggunakan istilah fenomenologi mengikuti pola konsepsi Engkus Koeswarno. Sebagaimana yang disebutkan dalam buku Fenomenologi, dirinya memperlihatkan bagaimana kajian Fenomenologi berhasil mengelaborasi suatu fenomena secara mendalam dan plural (Koeswarno, 2009). Inilah yang diharapkan dalam tulisan ini, suatu kajian mendalam dan plural.

Sungguhpun demikian, betapapun kerangka konsep fenomenologi dalam pandangan Koeswarno cukup relevan dalam menggali fenomena ini namun karena objek material dalam tulisan ini adalah suatu fenomena keagamaan, maka penulis juga mengombinasikan model fenomenologi Koeswarno dengan konsep Muhyar Fanani tentang Studi Agama. Dalam bukunya Metode Studi Islam, dia mengajukan pendekatan studi agama menggunakan model multi-perspektif (Muhyar Fanani, 2008: 219). Dengan demikian istilah fenomenologi dalam tulisan ini mengandung kerangka teoritik yang lengkap dengan mengkombinasikan berbagai teori di dalamnya untuk menghasilkan analisis yang tajam dan bisa dipertanggungjawabkan secara ilmiah.

Teknik pengumpulan data dalam penelitian ini menggunakan model interview mendalam, yakni dengan penggalian secara komprehensif data riset melalui aktivitas wawancara. Kemudian dokumentasi dilakukan dengan menerapkan model telaah dokumen secara integratif (integrative review). Tentunya, mengingat tulisan ini merupakan tulisan berparadigma riset fenomenologi, maka penulis menerapkan model breacketing data, yakni proes 'pengkranjangan' data riset. Ini digunakan untuk menghindari kesimpulan yang tergesa-gesa.

Istilah yang digunakan dalam pengumpulan data penelitian ini adalah informan dan key informan. Informan adalah subjek riset pada umumnya. Sementara itu, key informan diposisikan sebagai subjek yang berada setara dengan peneliti. Key informan dalam riset ini merupakan subjek riset yang memiliki kompetensi dan pemahaman yang mendalam tentang fenomena maupun kacamata kajian riset ini. Adapun teknik analisis data menggunakan model deskriptif interpretatif. Proses analisis dilaksanakan bersamaan dengan proses pengumpulan data. Hal ini semata mengikuti kerangka metodologis riset fenomenologi. Selain itu penulis juga menggunakan model reflektif untuk merefleksikan hasil riset di ujung tulisan.

\section{Hasil dan Pembahasan Konstruksi Sosial Masyarakat Muslim Lombok}

Sebagai daerah dengan penduduk mayoritas muslim, Lombok terkenal dengan 
Pulau seribu masjid. Penamaan sebagai pulau seribu masjid karena di sudut-sudut desa, atau bahkan dusun, terdapat masjid sebagai tempat ibadah dan pendidikan masyarakat. Sebagaimana catatan seorang peneliti seni asal Bandung, terdapat 3.767 masjid besar dan 5.184 masjid kecil di 518 desa di Lombok(Republika, 2018). Adapaun identitas keagamaan yang berkembang di pulau Lombok bercorak muslim yang berafiliasi ke model ahlus sunnah wal jamaah (Djamaluddin, 2011).

Aktor keagamaan yang paling berpengaruh dalam konstruksi sosial keagamaan masyarakat Lombok adalah Tuan Guru (Fahrurrozi, 2018). Dalam tradisi Jawa, tuan guru setara dengan kiai. Yakni orang yang ditokohkan, memiliki pengetahuan keagamaan yang mendalam. Para Tuan Guru biasanya menjadi tempat bertanya masyarakat tentang masalah keagamaan mereka, terutama persoalan hukum-hukum fikih. Karenanya, dalam setiap persoalan keagamaan, masyarakat Lombok umumnya merujuk ke tuan guru.

Fakta tersebut menunjukkan bahwa masyarakat muslim Lombok secara umum tidak memiliki bekal pengetahuan yang memadai tentang perangkat fikih guna menyikapi suatu persoalan. Itulah mengapa saat pandemi, ketika ada masalah mereka biasanya akan merujuk ke keterangan para tuan guru. Dan, seperti yang akan kita lihat nanti, sikap masyarakat Lombok yang seperti ini yang menjadikan terbentuknya 'kesalahpahaman' antara produk MUI dengan produk tuan guru yang mereka terima.

Secara teologis, masyarakat muslim Lombok masih berada dalam jaring-jaring identitas masa silam. Sebagaimana yang banyak disebutkan dalam berbagai referensi, masyarakat muslim Lombok terbagi ke dalam dua tipe yakni muslim Waktu Lima dan muslim Wetu Telu (Eka Budiwanti, 2000). Islam waktu lima diasosiasikan sebagai Islam yang sempurna, dan Islam Wetu Telu lebih sebagai Islam yang sinkretis karena ritual keagamaannya masih banyak berbau ajaran nenek moyang. Tanda utama pengikut Islam Wetu Telu adalah tidak menunaikan salat lima waktu, melainkan hanya 3 waktu dalam satu tahun (sungguhpun banyak sekali perbedaan pendapat tentang hal ini). Namun demikian, di era pasca Orde Baru, konstruksi sosial keagamaan Lombok bertransformasi seiring dengan perubahan sosial melalui perkembangan ilmu pengetahuan dan teknologi (Avoneus, 2004). Penulis sendiri menyebut bahwa pola identitas keagamaan masyarakat muslim Lombok unik, yakni terformat dalam proses negosiasi teologis yang canggih (War'i, 2020).

Pada prinsipnya model keberagamaan masyarakat Lombok masih diwarnai oleh identitas-identitas nenek moyang yang termanifestasi dalam berbagai tradisi yang masih hidup hingga saat ini. Ada perang topat. Yakni sebuah tradisi yang dilakukan di Lombok Barat. Salah satu tulisan tentang Perang Topat yang menarik adalah tulisan dari guru besar UIN Mataram, Prof. Suprapto (Suprapto, 2017), Maulid Petagan. Yakni tradisi maulid Nabi Muhammad yang dipadukan dengan tradisi adat di lokal kebudayaan desa Lendang Nangka di Lombok Timur, Ziarah Makam Leluhur, dan lain sebagainya. Kenyataan masyarakat Lombok yang berlatar sosial keagamaan sebagaimana keterangan di atas mendorong masyarakat Lombok dalam tradisi keagamaan yang inklusif. Namun demikian dalam hal referensi fikih, masyarakat muslim Lombok tetap terpaku pada keterangan para tuan guru.

Lekatnya hubungan masyarakat Lombok dengan Tuan Guru dalam persoalan fikih di satu sisi menjadi hal positif karena masyarakat memiliki sumber pemahaman hukum yang kredibel dari ahlinya. Namun di sisi lain, menjadi salah satu faktor yang melahirkan polemik saat implementasi fatwa hukum Covid-19 diterapkan oleh pemerintah.

\section{Polemik Sosial Fatwa MUI tentang Libur Jumat}

Diimplementasikannya fatwa MUI tentang ibadah di tengah wabah yang di antara poin fatwa di dalamnya adalah pelarangan salat berjamaah di masjid, salat 
Jumat, salat ied, telah menjadi faktor lahirnya 'kegelisahan sosial' di kalangan masyarakat muslim Indonesia. Sebelumnya, Fatwa MUI Nomor 14 tahun 2020 berisi 11 poin ketentuan, 3 rekomendasi, dan 2 penutup (MUI, 2020). Di antara poin-poin fatwa tersebut, pelarangan ibadah di masjid termasuk salat Jumat menjadi poin yang paling banyak disorot. Sebagai negeri mayoritas muslim, dengan status 'wajib' dari ritual keagamaan yang dilarang, konflik sosial tersebut merupakan hal yang niscaya. Namun demikian, terjadinya konflik sosial ini menjadi mengkhawatirkan saat konflik tersebut menjelma konflik besar yang cukup mengkhawatirkan. Sebagaimana yang disebutkan pada bahasan sebelumnya, di Lombok khususnya terjadi konflik sosial yang bahkan sampai berujung pertengkaran berdarah.

Lombok sebagai pulau dengan demografi muslim terbesar dan dengan masjid-masjid yang sangat banyak hingga dikenal sebagai pulau seribu masjid, tentunya mengalami pukulan psikologis yang keras dengan adanya fatwa tersebut. Di berbagai tempat yang tersebar di pualu Lombok, terjadi insiden yang melibatkan masyarakat dengan petugas dari kepolisian maupun TNI yang bertugas menertibkan masjid yang masih 'beroperasi' di masa pandemi (Azizah \& Nuruddin, 2021).

Sebagaimana pada awal-awal kebijakan penanganan Covid-19, seluruh tempattempat ibadah ditutup. Kebijakan ini berlandaskan pada fatwa MUI tentang ibadah di tengah wabah. Namun demikian, karena kedekatan psikologis masyarakat muslim Lombok dengan masjid sebagai sentral ibadah mereka, terjadi pergesekan yang kemudian melahirkan konflik.

Dalam beberapa kanal media, juga dari pengamatan penulis sendiri nampak konflik masyarakat yang terjadi antara masyarakat muslim dengan polisi dan TNI. Di Desa Banok, Lombok Timur, masyarakat Muslim yang berangkat ke masjid membawa senjata tajam. Ketika ditanya alasannya, mereka menjawab untuk berjaga-jaga kalau ada polisi ataupun TNI yang datang 'sidak' ke tempat mereka (Hariadi (37), 2021). Di
Janapria desa Lombok Tengah, juga terjadi perkelahian antara polisi dan masyarakat, bahkan salah satu tokoh agama ada yang ditangkap karena mengajak masyarakat untuk tidak mengikuti Fatwa MUI melalui mimbar khotib (Koran Suara NTB, Edisi 8 April 2020). Sementara itu di Desa Danger Kecamatan Masbagik, Lombok Timur, terjadi ketegangan yang melibatkan satgas Covid dari perangkat desa dan kecamatan dengan beberapa anggota masyarakat di desa tersebut.

Dalam teori sosiologi, konflik biasanya terjadi karena adanya perbedaan antara masyarakat. Perbedaan tersebut bisa berbentuk hal yang membangun dan yang tidak membangun. Oleh karena itu secara keorganisasian, konflik dibagi menjadi dua, yakni konflik yang bersifat fungsional dan konflik yang bersifat disfungsional. Fungsional berarti bahwa konflik yang terjadi mengarah kepada perubahan yang konstruktif, sedangkan disfungsional berarti bahwa suatu konflik mengarah kepada halhal destruktif dan merusak serta tidak produktif bagi masyarakat (Mark Abrahamson, 2003). Sedangkan berdasarkan waktu, konflik dapat dibedakan menajdi konflik sesaat dan berkelanjutan (Ayub Rustiani, 2021).

Terkait dengan konflik implementasi fatwa MUI di Lombok, maka bisa dipetakan bahwa konflik ini masih bersifat sesaat namun tidak menutup kemungkinan akan berdinamika menjadi konflik yang berkelanjutan. Oleh karena itu, sangat penting untuk segera mengambil langkahlangkah preventif untuk mencegah hal-hal lain yang lebih serius. Dan secara keorganisasian, perbedaan konsepsi dalam penerapan fatwa MUI di Lombok telah nyata menjurus kepada konflik yang disfungsional. Artinya, kenyataan tersebut kontra produktif dengan kemajuan yang ingin dicapai oleh komunitas masyarakat tersebut.

Terjadinya konflik antar komunitas masyarakat terkait implementasi fatwa MUI menjadi benih konflik sosial yang perlu diperhatikan. Beberapa kasus pertikaian antara petugas keamanan dengan 
masyarakat di atas bermula dari dua bentang paradigma yang saling berseberangan. Di satu sisi, para petugas keamanan menggunakan alasan aturan pemerintah yang menggunakan fatwa MUI sebagai landasan. Di sisi lain, masyarakat tetap bersikeras untuk salat Jumat karena banyak faktor yang mengelilinginya, seperti faktor psikologis, budaya, agama, dan lainnya.

Bapak Asmawadi (43 th) menyebutkan bahwa dirinya merasa tidak enak hati untuk meninggalkan Jumatan, karena dirinya beranggapan bahwa kewajiban tersebut tidak bisa ditinggalkan begitu saja (Asmawadi, 2021). Jawaban Bapak Asmawadi ini mengindikasikan bahwa ada faktor psikologis yang bergelayut dalam proses negosiasi identitas keagamaan untuk melakukan perubahan yang cukup 'ekstrim' yakni dari hal wajib menjadi hal yang 'tidak boleh' dilakukan.

Kenyataan tersebut sejalan dengan beberapa orang yang penulis wawancarai, Agus Munadi (40th), juga dengan berapi-api menyampaikan argumentasi bahwa salat Jumat adalah hal yang wajib dan tidak boleh ditinggalkan bahkan meskipun segawat apapun keadaannya. "Covid itu tidak nampak, belum jelas keberadaannya, dan salat Jumat itu jelas wajibnya!" Ungkapnya kala itu (Agus Nadi, 2021). Ketidakmenerimaan masyarakat muslim ini sepertinya menjadi hal yang kompleks karena melibatkan psikologis seseorang yang terbingkai dalam struktur sosial keagamaan yang rumit.

Ibnu Khaldun dalam teori konfliknya mengungkapkan bahwa secara alamiah manusia memiliki kecendrungan untuk mencintai identitas kelompok mereka (Hakimul Ikhwan Affandi, 2004). Dalam hal ini perangkat atau sistem identitas yang melekat pada mereka menjadi 'baju' sosial yang sulit untuk ditanggalkan. Terjadinya ketidakmenerimaan beberapa komunitas masyarakat bisa jadi dipengaruhi oleh sikap menjaga identitas keagamaan mereka yang telah terlanjur mengakar dalam diri mereka. Fikih (ketentuan wajib Jumatan) sebagai salah satu perangkat identitas yang membangun tradisi keagamaan mereka telah menjadi satu perangkat yang sangat penting yang tidak begitu saja bisa ditanggalkan. Sebagaimana catatan Van Bruinessen, tradisi fikih di Indonesia secara umum telah tumbuh sejak abad ke-17 (Martin van Bruinessen, 2012).

Selain alasan psikologis, proses implementasi fatwa MUI tentang libur Jumat dan ritual ibadah lainnya di tengah pandemi mengalami kendala dan berujung konflik karena belum seragamnya tokoh agama maupun masyarakat dalam menerima fatwa MUI itu. Di salah satu desa di Lombok Timur, tokoh agamanya dengan keras menolak fatwa MUI dan mengangap hal tersebut berlebihan. Kenyataan ini akhirnya mendorong masyarakat juga tidak sepakat dengan fatwa tersebut.

Di sebuah desa di Lombok Tengah juga khatib yang dengan tegas mengungkapkan di salah satu khutbahnya di hari Jumat tentang ketidakmenerimaannya terhadap fatwa MUI tersebut yang kemudian berujung kepada penangkapan yang bersangkutan oleh pihak kepolisian. Dalam khutbahnya, tokoh tersebut dengan tegas menganggap bahwa mengikuti fatwa MUI adalah tindakan di luar iman (kafir) (Koran Suara NTB, 2020). Dirinya mengklaim bahwa ibadah akan menghilangkan pandemi, bukan sebaliknya, oleh sebab itu tidak seharusnya meninggalkan ibadah di saat wabah Corona melanda. Tuan Guru tersebut mengklaim bahwa libur Jumat sebagai bentuk meninggalkan ibadah.

Proses implementasi fatwa MUI semakin terjerat dalam konflik sosial yang rumit ketika alasan masyarakat tidak bisa mengikuti fatwa tersebut adalah karena mereka telah terbiasa melakukan salat jamaah, Jumatan, dan aktivitas berjamaah lainnya. 'Suatu yang sudah mentradisi' memang sulit untuk dibelokkan, apalagi dihentikan. Dalam kajian kebudayaan tradisi adalah suatu yang sangat integral dalam kultur komunitas masyarakat (Stella Ting-Toomy, 1991). Oleh karena itu ketika salat Jumat, salat berjamaah, dan lainnya telah mentradisi dalam komunitas masyarakat muslim, maka ketika ada 
larangan untuk meninggalkan hal itu, terlepas dari tujuannya yang baik, tetap akan memunculkan konflik.

Tambahan pula, implementasi fatwa MUI di tengah komunitas masyarakat yang beragam faktanya telah menjadi perantara meruncingnya hubungan yang tidak sehat antar masyarakat itu sendiri. Sebagaimana temuan penulis dalam komunitas muslim di Lombok Timur, pertentangan tidak hanya terjadi antara masyarakat dan satgas covid saja, tetapi juga antar masyarakat, yakni antara masyarakat yang mengikuti fatwa dengan masyarakat yang tidak mengikuti fatwa

"Orang-orang yang tidak mengikuti salat Jumat dan memilih salat sendiri di masjid, harus mempertanggungjawabkan dosanya" ungkap Safarul, salah seorang warga desa Lendang Nangka yang tidak mau mengikuti himbauan pemerintah. Oleh karena itu, dirinya dengan orang-orang yang sepaham dengannya mengadakan salat Jumat secara sembunyi-sembunyi yakni dengan memanfaatkan salah satu musholla yang terdapat di tengah kampung.

Melihat orang-orang yang tidak mengikuti pemerintah, golongan masyarakat yang mengikuti arahan pemerintah untuk meniadakan salat Jumat memberikan komentar, "mereka orangorang yang tidak paham hukum fikih. Padahal para ulama telah merumuskannya. Kita harus mematuhinya." Komentar semacam ini banyak terdengar dari kalangan masyarakat yang mengikuti fatwa MUI Nomor 14 tersebut. Dualitas pemahaman tersebut menjadi salah satu yang memicu terjadinya pembelahan sosial di kalangan masyarakat muslim Lombok.

Pembelahan sosial ini diafirmasi oleh berbagai konsep teori konflik yang ada. Ibnu Khaldun dalam lanjutan argumentasinya tentang konflik menyebut bahwa sikap agresif komunitas masyarakat akan muncul tatakala simbol dari identitas yang mereka anut tengah terancam (Hakimul Ikhwan Affandi, 2004: 85). Dalam hal ini, para pengikut aliran fikih wajib Jumatan melihat bahwa meninggalkan salat Jumat merupakan bentuk pelecehan terhadap simbol keagamaan yang mereka yakini. Di sisi lain, komunitas yang berseberangan melihat bahwa sikap bersikeras sebagai kelompok muslim terhadap fatwa libur Jumatan merupakan bentuk tidak menghormati ulama, dan menganggap diri mereka lebih pintar dari pada para ulama.

Dalam hal ini, benih-benih konflik begitu jelas tercium. Bahwa ancaman pertikaian sosial telah siap menjadi kelanjutan dari ancaman psikologis yang muncul dari berseberangannya dua paradigma fikih yang telah melahirkan jarak sosial yang cukup jauh. Sangat dikhawatirkan jika pandemi masih belum melandai sementara fatwa MUI tentang ibadah di tengah wabah Covid 19 masih menjadi kebijakan pemerintah yang perlu ditati dan diikuti dalam ritual peribadatan.

Dialog apapun, apalagi dalam konteks teologis, tidaklah sederhana. Implementasi fatwa MUI tentang ibadah di tengah pandemi wabah memang tak dipungkiri telah melewati standar metodologi fikih yang kredibel, namun produk apapun ketika memasuki ruang tradisi sosial masyarakat harus berhadapan dengan berbagai friksi yang mengelilingi. Stella Ting-Toomy melalui teori negosiasi identitas memberikan gambaran bahwa saat seseorang menemukan hal baru yang berseberangan dengan identitas awal mereka, maka akan terjadi proses negosiasi antara idenitas dirinya yang telah ada lebih dulu dengan tradisi baru yang menjamah tradisi yang mereka imani (percayai) (Stella Ting-Toomy, 1991: 15). Inilah yang nampak mengemuka pada tradisi masyarakat muslim di pulau Lombok, saat fatwa MUI tentang pembatasan ritual keagamaan (berjamaah dan Jumatan di masjid) segera terjadi penolakan.

Bagian ini dapat disimpulkan bahwa implementasi fatwa MUI tentang ibadah di tengah wabah telah direspon beragam oleh masyarakat. Ada yang menerima dan banyak juga yang menolak sehingga memunculkan konflik sosial karena adanya goncangan psikologis, keyakinan keagamaan, dan tradisi yang sudah mengakar. Tiga hal ini menjadi hal 
mendasar yang perlu diperhatikan untuk merekonsiliasi konflik sosial keagamaan yang terjadi di era pandemi ini.

\section{Dualitas Nalar Fikih; Normatif versus Historis?}

Sebelum uraian tentang sub bahasan ini, perlu penulis tuangkan beberapa penjelasan seputar referensi teoritik penggunaan kata 'nalar' fikih ini. Istilah nalar sebagaimana dalam terminologi Abeed Aljabiri mengandung komposisi yang kompleks. Dibandingkan dengan 'pemikiran' atau 'ideologi', 'nalar' memiliki sistem asosiasi yang lebih luas. Dalam kitab-nya, Bunyatu Aqlil Araby, Aljabiri, mengutip salah seorang filsuf Perancis bahwa nalar memiliki sisi sosial kebudayaan yang sebagaimana dikatakan Levis-Strauss sebagai 'nalar dominan'. Dalam pandangan Aljabiri 'nalar' ('aql) dibagi dua yakni nalar aktif dan nalar dominan. Dalam nalar dominan tercakup di dalamnya latar sosial budaya seseorang. Artinya perangkat nalar mengandung berbagai aspek yang mempengaruhi cara berpikir seseorang. Dalam hal ini aspek pendidikan, sosial, kebudayaan, agama, dan lainnya menjadi komponen yang membangun nalar seseorang. Karena itulah nalar dalam perspektif Aljabiri merujuk kepada 'nalar dominan'(Aljabiri, 2009: 12, 251, 383).

Penggunaan istilah nalar fikih dalam tulisan ini mengacu pada bagaimana pemahaman masyarakat muslim Lombok dalam menyikapi dan merespon hasil fatwa MUI terutama setelah menjadi 'tangan' pemerintah dalam menerapkan suatu kebijakan. Penggunaaan istilah nalar ini untuk membuka ruang analisis yang lebih luas dan dinamis dengan menghadirkan aspek sosiologis, antropologis, kebudayaan di balik model penerimaan mereka terhadap sebuah fatwa keagamaan.

Sebagaimana yang akan kita lihat nanti, nalar fikih masyarakat muslim di pulau seribu masjid mengemuka dalam pola-pola yang beragam. Artinya banyak aspek yang mempengaruhi sikap seseorang dalam menerima atau menolak fatwa MUI, seperti faktor sosiologis, antropologis, psikologis dan lainnya. Oleh karena itu, tulisan ini menggunakan berbagai pendekatan (anything goes) dalam proses analisisnya guna benar-benar menghadirkan konsep tersebut secara utuh.

Fikih sebagai produk keagamaan yang seringkali bersifat final menjadi salah satu kendala dalam perpaduaun istilah nalar dan fikih ini. Namun demikian, penulis tetap akan menggunakan istilah ini untuk menggambarkan bagaimana sesungguhnya dalam produk fikih yang statis, ada objek fikih yang dinamis. Penilaian tentang nalar fikih yang cendrung statis ini dibahas oleh Asmuni dalam tulisannya Krisis Nalar Fikih (Asmuni, 2019). Memahami hakekat dasar produk fikih seharusnya menjadi bagian yang integral dalam melihat implementasi suatu produk hukum (fatwa) terlebih jika menjadi 'amunisi' pemerintah dalam menerapkan kebijakannya.

Dalam tulisan ini nalar fikih yang dimaksud adalah nalar fikih masyarakat di satu sisi, dan di sisi yang lain adalah nalar fikih pemerintah selaku pemangku kebijakan yang menggunakan fatwa MUI sebagai senjata untuk merevolusi tradisi keagamaan yang ada di masa non-pandemi untuk diubah dan disesuaikan dengan ibadah di masa pandemi.

Konflik sosial keagamaan yang terjadi sebagaimana pembahasan sebelumnya menunjukkan bahwa ada pertentangan konseptual antara pemerintah yang menggunakan fatwa MUI dengan masyarakat sebagai objek fatwa atau kebijakan. Meskipun telah maklum bahwa proses produksi fatwa MUI tentunya menjalani serangkaian kerangka Ushul Fikih yang tidak sederhana termasuk pertimbangan rasionalitas dan bahkan intuitisitas (Agustina, 2020), tetapi saat hasil fatwa berbentuk produk hukum yang final, maka status produk tersebut bergantung di tiang normativitas. Artinya produk hukum dalam tataran tertentu adalah suatu sumber hukum yang tak bisa ditawar.

Itulah yang mewarnai fenomena implementasi fatwa MUI tentang ibadah di tengah wabah. Pemerintah selaku pemangku kebijakan yang menggunakan 
hasil fatwa MUI dalam mengendalikan virus Corona cenderung memaknai hasil fatwa MUI sebagai hal yang final. Ini terlihat dari pernyataan Bupati Lombok Timur, H. Sukiman Azmi sebagai Ketua Satgas penanganan Covid di daerah tersebut yang mengatakan bahwa kebijakan peniadaan salat berjamaah dan salat Jumat adalah fatwa ulama-ulama terkemuka. "Orang yang tidak mematuhi fatwa ini berarti merasa lebih alim dari ulama-ulama tersebut?" Ungkapnya dalam salah satu video yang beredar melalui aplikasi WhatsApp. Video tersebut telah diupload oleh akun youtube suara NTB yang mengarsipkan video tersebut dengan judul video: Bupati Lotim: Tak Ada Lagi Toleransi, Bubarkan Kerumunan Orang! (SUARANTBcom. via Youtube di situs: https://youtu.be/ev58CtxEOJM).

Pernyataan bupati tersebut menjadi salah satu contoh bagaimana fatwa MUI telah menempati posisi finalitas yang tak bisa ditawar. Ini tentu menjadi hal yang klise saat berbenturan dengan tradisi sosial keagamaan. Sebagaimana yang disinggung sebelumnya, betapapun produk hukum MUI telah melewati standar proses fatwa yang valid, namun implementasi produk hukum di tengah masyarakat tidaklah sesederhana mengeluarkan hasil fatwa dalam satu lembaran surat!

Kejadian di berbagai tempat di pulau Lombok menjadi satu indikator penting bahwa implementasi fatwa tidak bisa tergesa-gesa dan apalagi memaksa! Kenyataan bahwa aparat penegak hukum yang seringkali menggunakan kekerasan dalam mengendalikan massa di beberapa masjid menambah catatan penting tentang bagaimana fatwa MUI telah diangkat dalam derajat kevalidan yang tak cacat dan tak boleh di bantah.

Pola pemahaman pemerintah disini penulis posisikan sebagai nalar hukum produk MUI. Artinya penulis mereferensikan istilah nalar fikih MUI disini sebagai nalar fikih yang digunakan pemerintah (satgas Covid) dengan menggunakan fatwa MUI sebagai landasan keagamaan dalam mengambil kebijakan ibadah di masa pandemi. Dalam kajian studi Islam, pola pemahaman yang digunakan pemerintah disini sangat normatif. Sebagaimana Amin Abdullah, normativitas merujuk kepada suatu sikap keagamaan yang terpaku pada suatu teks (Amin Abdullah, 2012). Dalam hal ini fatwa MUI sebagai teks keagamaan telah dipahami sebagai sumber yang otoritatif meskipun setelah diimplementasikan menjadi berbau otoriter.

Khaled Aboe Fadl mengingatkan bahwa produk hukum tidaklah sama dengan sumber hukum. Seperti halanya ayat Alquran tidaklah sama dengan tafsir ayat Alquran (Khaled Aboe Fadl, 2003). Penulis tidak menuduh MUI sebagai lembaga fatwa yang otoriter, tetapi seringkali hasil fatwa MUI dijadikan oleh oknum tertentu sebagai tangan baja untuk menekan masyarakat yang tidak sepaham dengan kebijakan pemerintah.

Perlu penulis konfirmasi, bahwa sitilah normatif tidaklah merujuk secara purna kepada konsep Amin Abdullah maupun Fazlur Rahman. Dalam analisis ini, penulis hanya menggunakan istilah ini secara etimologis, yakni menunjukkan kepada makna leksikologis. Artinya, penggunaan referensi makna kata ini untuk kepentingan analisis. Sejatinya penulis memiliki beberapa opsi untuk pemaparan analisis ini, seperti istilah tekstual versus kontekstual, atau fanatik vs despotik, namun istilah-istilah tersebut masih belum populer dan tidak bisa mengalternasi fenomena yang sedang penulis uraikan.

Normatif, dengan demikian, ditunjukkan kepada keadaan masyarakat yang masih terpaku pada referensi tekstual. Dalam hal ini produk hukum MUI merupakan teks yang secara utuh diterapkan oleh satgas Covid dalam menekan masyarakat untuk menjalankan kebijakan penangan penularan Covid-19. Adapun historis ditunjukkan kepada makna etimologisnya yakni aspek kesejarahan. Artinya referensi fikih yang digunakan masyarakat Lombok secara umum terpaku pada produk fikih yang telah terbentang dalam sejarah pemahaman tradisi fikih 
mereka. Dengan demikian normatif versus historis ini tidak seutuhnya mengacu pada konsep Amin Abdullah.

Selanjutnya, sikap normatif yang dianggap sakral itu kemudian akan mengantarkan kepada sikap ekslusifitas yang berbahaya. Oleh karena itu normativitas seharusnya disandingkan dengan historisitas. Hal ini berarti pemahaman teks harus diikuti dengan pemahaman ruang dimana teks itu berada. Fatwa MUI sebagai suatu teks harus dipahami lengkap dengan latar hukum berupa aspek sosial, politik, kebudayaan, pemahaman keagamaan, dan lainnya. Inilah yang disebut Fazlurrahman sebagai pemahaman hulu-hilir (Amin Abdullah, 2012; Fazlur Rahman, 1984).

Saat pemerintah menggunakan pola pemaknaan normatif dalam melihat fatwa MUI, masyarakat sebagai objek fatwa justru menggunakan pola pemaknaan historis, yakni dengan mendefinisikan aturan-aturan keagamaan mereka sebagai suatu turunan dari para pendahulu juga sebagai kebiasaan yang sudah menjadi bagian yang tak terpisahkan dalam diri mereka.

Irfan Jayadi (45), salah satu informan yang penulis wawancarai, menyebutkan dengan tegas bahwa kewajiban salat Jumat adalah aturan agama yang tidak bisa ditorerir. "Sepanjang sejarah hidup saya, tidak pernah sekalipun ada masalah atau alasan yang membolehkan untuk tidak salat Jumat, kecuali kalau benar-benar keadaan sakit," ungkapnya. Dirinya menilai bahwa keputusan libur Jumat adalah tergesa-gesa dan tidak berdasar.

Keterangan dari informan tersebut menguatkan informan-informan lainnya sebagaimana yang sudah lebih dulu penulis ungkapkan. Ini menunjukkan bahwa ada pertentangan pola pemaknaan hukum yang dilakukan oleh dua elemen yang berbeda yakni pemerintah selaku pemegang fatwa MUI dan masyarakat sebagai objek kebijakan tersebut.

Dapat disimpulkan bahwa model penalaran hukum fikih yang digunakan pemerintah secara umum adalah model pemaknaan tekstual (normatif) sehingga memunculkan sikap merasa benar sendiri dan menutup diri dari mendengarkan argumentasi orang lain. Di sisi lain, masyarakat menggunakan pola pemaknaan historis (keterpakuan pada adat tradisi keagamaan yang berlaku sejak lama), dengan meyakini bahwa apa yang mereka warisi dari pedahulu mereka adalah nilainilai keagamaan yang benar dan harus dipertahankan.

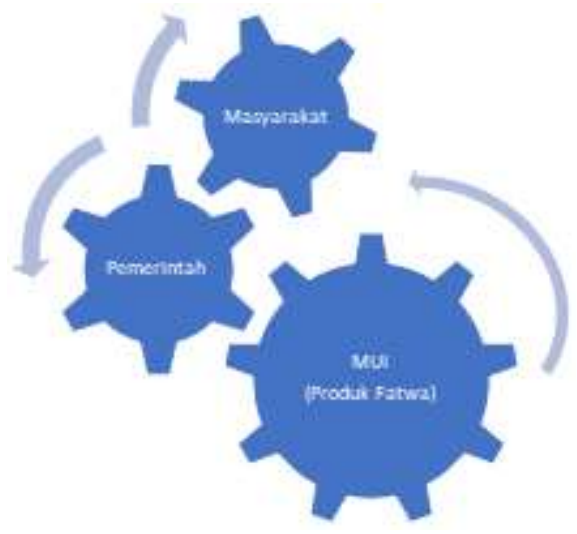

Gambar: Skema dualitas nalar fikih yang berseberangan: Normatif vs Historis

\section{Nalar Fikih Inklusif; Membuka Keran Dialog}

Temuan riset dalam tulisan ini menghasilkan peta takaran nalar fikih yang dimiliki oleh masyarakat muslim khususnya di pulau seribu masjid, Lombok. Berdasarkan pada analisis sebelumnya, format nalar fikih yang berkembang di komunitas masyarakat tersebut. Meminjam Abeed Aljabiri model penalaran tersebut terkungkung dalam pola nalar bayani, yakni pemahaman yang berlandaskan pada tekstualitas. Konsep Abeed Aljabiri yang terkenal adalah tiga epistemologi pengetahuan yaitu Bayani, Burhani, dan Irfani. Bayani adalah pemaknaan tekstual dari sumber-sumber literal semata. Burhani adalah pemerolehan pengetahuan melalui rasio, dan Irfani adalah pemerolehan pengetahuan melalui intuisi (Aljabiri, 2009). Artinya, pemahaman nalar fikih masyarakat hanya tergantung pada apa yang disebutkan oleh tuan guru. Bahayanya, pandangan tuan guru yang diambil juga sering kali hanya melakukan proses istinbath hukum dengan 
sederhana dan tidak komprehensif.

Dalam pandangan Aljabiri, model pemaknaan bayani ini selalu cukup dengan keterangan-keterangan tekstual dan tidak menggunakan rasio apalagi intuisi dalam proses pemaknaannya. Oleh karena itu hasil dari olah pandang menggunakan metode bayani sering kali melahirkan paradigma yang ekslusif atau jumud (Amin Abdullah, 2012: 125). Melihat sikap beberapa kelompok muslim di Lombok, sepertinya pola ini masih menjadi pola dominan pemaknaan hukum fikih di pulau seribu masjid itu.

Ketika di satu sisi masyarakat menggunakan nalar fikih yang bersifat historis dan di sisi yang lain satgas covid berada dalam formasi pemaknaan normatif yakni dengan menggunakan hasil fatwa MUI sebagai dalil dalam pembatasan sosial masyarakat dalam ibadah. Celakanya satu sama lain menganggap sumber hukum yang mereka gunakan adalah yang paling benar, dan karenanya setiap yang berseberangan dengan fatwa itu dianggap tidak benar, atau kurang ajar.

Peta nalar fikih ini penting diketahui dan dipelajari lebih lanjut oleh lembaga fatwa MUI. Ini mengingat bahwa sesungguhnya tujuan dari organisasi MUI sendiri adalah untuk menebarkan nilai-nilai keislaman yang rahmatan lil alamin (MUI, 2020), yaitu kedamaian di seluruh penjuru alam semesta ini. Tujuan tersebut tentu sulit akan terwujud jika kenyataan sosial menunjukkan bahwa objek fatwa hukum yang dikeluarkan MUI memilki model pemaknaan yang tekstual sebagaimana disebutkan.

Dalam hal ini, MUI perlu mempelajari lebih dalam dan serius pola konstruksi sosial keagamaan masyarakat sebelum mengimplementasikan fatwa keagamaan yang diinisiasi oleh pemerintah. Proses dialog mutlak diperlukan dalam memberlakukan secara konstitusional sebuah fatwa. Terkait hal ini, MUI pusat perlu terus melakukan komunikasi dengan MUI daerah untuk mendiskusikan laporan seputar kondisi sosial keagamaan, sehingga di masa depan konflik semacam ini dapat dihindari.

Ketika penulis melakukan diskusi dengan beberapa orang yang berada di komisi Fatwa MUI, ada banyak miskomunikasi yang muncul saat implementasi fatwa MUI sebagai kebijakan pemerintah. KH. Hamdan Rasyid, misalnya, memberikan pernyataan tegas, bahwa seringkali hasil fatwa MUI disalahpahami karena tidak dibaca secara komprehensif. Misalnya, poin-poin yang ada dalam Fatwa MUI nomor 14 tentang Ibadah di tengah pandemi Covid-19, tidak ada yang berisi penutupan masjid, tetapi dalam implementasinya satgas Covid, justru melakukan penutupan masjid bahkan melakukan sweeping terhadap masjid-masjid yang masih buka.

Demikian pula saat KH. Sirrul Wafa memberikan komentar pada acara Annual Conference on Fatwa Studies 5, dirinya menyayangkan sikap beberapa satgas Covid-19 yang bertugas di lapangan seringkali membuat keputusan yang tidak sesuai dengan poin fatwa, tetapi saat diprotes masyarakat mereka mengklaim bahwa mereka mengikuti hasil fatwa MUI. Ini menunjukkan bahwa ada lubang yang teramat menganga antara MUI dan Pemerintah dalam hal komunikasi dialogis perihal fatwa. Hal ini disadari oleh Prof. Sutarmadi selaku salah satu anggota di Komisi fatwa bahwa selama ini komunikasi antara MUI dengan Pemerintah maupun masyarakat masih belum maksimal terutama dalam konteks implementasi fatwa. Hal ini disampaikan pada acara Annual Conference on Fatwa Studies yang diadakan di Jakarta pada tanggal 26-28 Juli 2021 (Sutarmadi, 2021).

Dari data tersebut, maka sangat penting dibuka keran dialog yang melibatkan ulama (MUI), umara' (pemerintah), dan mujtama' (masyarakat). Keterpasungan jarak antara ketiga elemen penting tersebut akan melahirkan bangunan sosial-keagamaan yang rapuh dan rawan konflik. Artinya saat ketiga elemen tersebut tidak terkoneksikan dengan baik dalam proses implementasi fatwa, maka konflik-konflik sebagaimana yang dihadirkan di muka tidak bisa 
terhindarkan, baik saat ini maupun di masa depan.

Penulis percaya, bahwa MUI tidaklah ingin membiarkan fatwanya disalahpahami apalagi disalahgunakan (seperti membuat keresahan publik), karena prinsip yang dibangun adalah mengedukasi masyarakat tentang prinsip-prinsip keagamaannya. Namun, jika berdiam atas fakta polemik yang terjadi saat implementasi fatwa dilaksanakan, maka itu adalah bentuk afirmasi MUI secara kelembagaan yang tentunya akan menciderai tujuan luhur dari organisasi Majelis Ulama Indonesia itu sendiri.
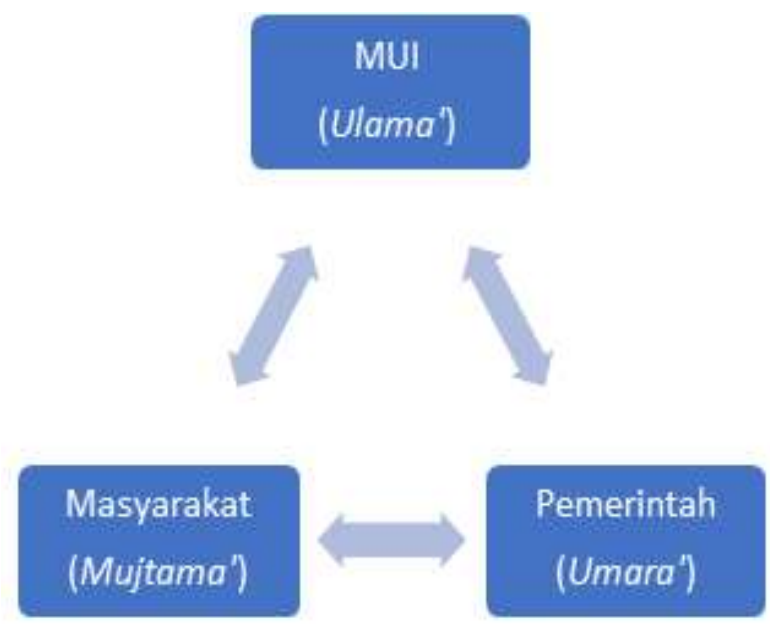

Gambar: Formasi Dialog dalam Membangun Nalar Fikih Inklusif

Dibutuhkan proses dialogis sebagai langkah persuasif dalam implementasi fatwa MUI yang dijadikan sebagai kebijakan pemerintah yang melibatkan unsur ulama, umara' dan mujtama' terutama yang bersifat ritual keagamaan agar tidak terkesan memaksa sehingga tidak memunculkan polemik lain di luar masalah fikih. Selain itu MUI selaku lembaga fatwa penting untuk melakukan edukasi terhadap masyarakat secara massif dengan mensinergikan unsur MUI (ulama), Pemerintah (umara'), dan masyarakat umum (mujtama').

Langkah strategis yang dilakukan oleh Bupati Lombok Barat, H. Fauzan Khalid dengan melakukan dialog bersama para tokoh agama dan masyarakat guna menyatukan persepsi tentang Covid-19, baik aspek bahayanya, maupun aspek penanganannya, menjadi sinyal baik konektivitas ulama dan umara' dalam penanganan covid 19. Tindakan ini merupakan contoh bagaimana pemerintah perlu duduk bersama para ulama dan masyarakat luas secara umum (suara NTB, 2020).

Kerjasama tiga unsur ini dalam menegosiasikan pemahaman fikih mereka untuk mendudukkan maksud dan tujuan suatu produk hukum (fatwa) akan mendorong terwujudnya nalar fikih yang inklusif. Nalar fikih inklusif adalah model ideal yang bisa digunakan untuk meminimalisir konflik dalam implementasi fatwa MUI terutama terkait fatwa ibadah di tengah wabah ketika pandemi covid-19 masih belum melandai.

\section{Penutup}

Tulisan ini dapat disimpulkan dalam beberapa poin. Pertama, respon masyarakat muslim lombok sebagai demografi dengan banyaknya masjid yang berdiri adalah adanya ketidakmenerimaan baik secara psikologis, sosial, dan kultural. Respon ini kemudian menunjukkan fatwa ulama yang terkesan memaksa dan minim dialog. Kedua, terjadi pertentangan konseptual antara pemerintah selaku pemegang fatwa MUI dengan konsep tradisi keagamaan masyarakat yang sebelumnya mereka yakini kebenarannya, sehingga fatwa libur Jumat memunculkan problem sosial keagamaan yang cukup mengkhawatirkan.

Ketiga, model penalaran hukum fikih yang digunakan pemerintah secara umum adalah model pemaknaan tekstual (normatif) sehingga memunculkan sikap merasa benar sendiri dan menutup diri dari mendengarkan argumentasi orang lain. Di sisi lain masyarakat menggunakan model pemaknaan historis dengan besikukuh pada pemahaman warisan dari pendahulu mereka.

Sebagai langkah solutif, dibutuhkan proses dialogis sebagai langkah persuasif dalam implementasi fatwa ulama yang dijadikan kebijakan pemerintah agar tidak 
terkesan memaksa dengan melibatkan unsur ulama, umara', dan mujtama'. Kerjasama tiga unsur ini dalam menegosiasikan pemahaman fikih mereka untuk mendudukkan maksud dan tujuan suatu produk hukum (fatwa) akan mendorong terwujudnya nalar fikih yang inklusif.

\section{Ucapan Terima Kasih}

Tulisan ini tuntas dikerjakan atas keterlibatan berbagai pihak. Penulis menyampaikan terima kasih atas bantuan dan masukan mereka. Ucapan terima kasih penulis sampaikan kepada para kolega yang telah banyak mewarnai alur pemikiran saya, terutama dalam tuntasnya tulisan ilmiah ini. Kedua, penulis juga ucapkan terima kasih kepada reviewer Jurnal Dialog yang telah memberikan masukan yang konstruktif terhadap tulisan ini. Berbagai arahan yang diberikan sungguh sangat membantu dalam perbaikan naskah ini sehingga menjadi naskah yang layak untuk dipublikasikan. Selain itu, penulis juga memberikan terima kasih kepada institusi penulis, Sekolah Tinggi Ilmu Tarbiyah Darussalimin NW Praya yang terus mendorong kami para dosen untuk terus melakukan penelitian dan publikasi ilmiah.[]

\section{Daftar Pustaka}

Agus Nadi. (12 Juli, 2021). Wawancara.

Agustina, A. M. (2020). Nalar Fikih Sufistik Fatwa Majelis Ulama Indonesia (MUI) dalam Merespons Pandemi Covid-19. Dinika Academic Journal of Islamic Studies, 2(4), 243-261.

Aljabiri, A. (2009). Bunyatul Aqlil Aroby: Dirosah Tahliliyah Naqdiyah li Nazhmil Ma'rifah fits Tsaqofatil Arobiyah. Baitun Nahdlah.

Amin Abdullah. (2012). Islamic Studies di Perguruan Tinggi Pendekatan IntegratifInterkonektif (1st ed.). Pustaka Pelajar.

Asmawadi. (12 Juli, 2021). Wawancara.

Asmuni. (2019). Krisis Nalar Fikih ( Pembacaan Perspektif Epistemologi
Jabirian Dan Hamadian ) Crisis Of Fiqh Reasoning ( Interpreting The Perspective Of Jabirian And Hamadian Epistemology ). Millah Jurnal Studi Agama, 18(2), 177-206.

Avoneus, L. (2004). Reforming Wetu Telu/ : Islam, Adat, and The Promises Of Regionalism In Post-New Order Lombok. Yliopistopaino.

Ayub Rustiani. (2021). Macam-macam Konflik Sosial dan Contohnya di Masyarakat. Tirto. www.tirto.id

Azizah, L., \& Nuruddin, N. (2021). Konflik Sosial Keagamaan Dimasa Pandemi Covid-19. SANGKéP: Jurnal Kajian Sosial Keagamaan, 4(1), 94-108. https:// doi.org/10.20414/sangkep.v2i2.p-ISSN

Dahlan, M. (2020). Respons Jamaah Tabligh Terhadap Fatwa Majlis Ulama Indonesia Tentang Covid-19). Qiyas, Jurnal Hukum Islam Dan Peradilan, 5(1), 53-69.

Djamaluddin. (2011). Sejarah Sosial Islam di Lombok Tahun 1740-1935. Kementerian Agama RI.

Eka Budiwanti. (2000). Islam Sasak: Wetu Telu Versus Waktu Lima. LkiS.

Fahrurrozi. (2018). Tuan guru and social change in Lombok, Indonesia. Indonesia and the Malay World, 46(135), 117-134. https://doi.org/10.1080/ 13639811.2018.1452487

Fazlur Rahman. (1984). Islam and Modernity: Transformastion on an Intellectual Tradition. Chicago University Press.

Hakimul Ikhwan Affandi. (2004). Akar Konflik Sepanjang Zaman Elaborasi Pemikiran Ibnu Khaldun. Pustaka Pelajar.

Hanafi, Y., Taufiq, A., Saefi, M., Ikhsan, M. A., Diyana, T. N., Hadiyanto, A., Purwanto, Y., \& Mawardi, A. I. (2020). Indonesian Ulema Council Fatwa On Religious Practices During Covid-19 Pandemic: An Investigation Of Muslim Compliance. 1-21. https://doi.org/ 10.21203/rs.3.rs-33784/v1 
Hariadi. (12 Juli, 2021). Wawancara.

Khaled Aboe Fadl. (2003). Atas Nama Tuhan dari Fikih Otoriter ke Fikih Otoritatif. PT. Serambi Ilmu Semesta.

Koeswarno, E. (2009). Fenomenologi Konsepsi, Pedoman, dan Contoh Penelitian. Widya Padjajaran.

Mark Abrahamson. (2003). Functional, Conflict and Neofunctional Theories. Dalam G. Ritzer (Ed.), Handbook and Social Theory (hal. 146-147). Sage Publications.

Martin van Bruinessen. (2012). Kitab Kuning, Pesantren, dan Tarekat. Gading Publishing.

Muhyar Fanani. (2008). Metode Studi Islam Aplikasi Sosiologi Pengetahuan sebagai Cara Pandang. Pustaka Pelajar.

MUI. (2020). Fatwa No 14 Tahun 2020 Penyelenggaraan Ibadah Dalam Situasi Terjadi Wabah Covid-19. Mui. https:// mui.or.id/berita/27674/.

Mushodiq, M. A., \& Imron, A. (2020). Peran Majelis Ulama Indonesia Dalam Mitigasi Pandemi Covid-19 (Tinjauan Tindakan Sosial dan Dominasi Kekuasaan Max Weber). SALAM: Jurnal Sosial Dan Budaya Syar-I, 7(5), 455-472. https://doi.org/10.15408/ sjsbs.v7i5.15315.

Republika. (2018). Asal Muasal Lombok Dikenal dengan Pulau Seribu Masjid. Republika. www.republika.co.id.

Rusyana, D. (2020). Fatwa Penyelenggaraan Ibadah di saat Pandemi Covid-19 di Indonesia dan Mesir. Perbandingan Mazhab Dan Hukum, UIN Sunan Gunung Djati Bandung (Unpublished), January, 1-14.

Stella Ting-Toomy. (1991). Communicating Across Culture. Guilford Press.

suara NTB. (2020, April). Sosialisasikan Fatwa MUI, Bupati Lobar Kunjungi Tuan Guru Jelaskan Bahaya Covid-19. Suarantb.Com. https://www.suarantb. com/sosialisasikan-fatwa-mui-bupati- lobar-kunjungi-tuan-guru-jelaskanbahaya-covid-19/

Suprapto. (2017). Sasak muslims and interreligious harmony: Ethnographic study of the perang topat festival in Lombok - Indonesia. Journal of Indonesian Islam, 11 (1), 77-98. https:// doi.org/10.15642/JIIS.2017.11.1.77-98

Sutarmadi. (2021). Annual Conference on Fatwa Studies 5.

War'i, M. (2020). Post-Theistic Negotiation Between Religion And Local Customs: Roles Of Indigenous Local Faiths In Lombok Island: Study Of Epistemology And Sociology Of Knowledge. Dialog, 43(2), 209-224. https://doi.org/10.47655/ dialog.v43i2.388

Zulkarnain, F., Nurdin, A., Gojali, N., \& Wahyu, F. P. (2020). Kebijakan Fatwa MUI Meliburkan Shalat Jumat Pada Masa Darurat Covid-19. Uinsgd, 1-11. http://digilib.uinsgd.ac.id/id/eprint/ 30733 